TITLE:

\title{
ON A NEW PRIMITIVE ALCYONARIAN, CORNULARIA KOMAII N. SP. FROM JAPAN
}

$\operatorname{AUTHOR}(S)$ :

Utinomi, Huzio

\section{CITATION:}

Utinomi, Huzio. ON A NEW PRIMITIVE ALCYONARIAN, CORNULARIA KOMAII N. SP. FROM JAPAN. PUBLICATIONS OF THE SETO MARINE BIOLOGICAL LABORATORY 1950, 1(3): 75-80

ISSUE DATE:

1950-10-05

URL:

http://hdl.handle.net/2433/174441

RIGHT: 


\title{
ON A NEW PRIMITIVE ALCYONARIAN, CORNULARIA KOMAII N. SP. FROM JAPAN*
}

\author{
Huzıo UTINOMI
}

With 3 Text-figur.

The stoloniferan to be deseribed in this paper is found very commonly in the littoral of Tanabe Bay off the Seto Laboratory, growing on the sheltered underside of rocks or under stones. At first sight, it appears something like egg mass of a certain fish or gastropod in the formation of a ribbon of pinkish beads. But while the specimen was brought to the laboratory and placed in a trough with running water, examination with a hand lens revealed at once the distinction, since each of the "beads" elongates and bears eight tentacles on the top. Thus it is evident that it is a form of the stoloniferous alcyonarian.

Apparently this alcyonaran resembles Clavularia gotoi OKuBo (1929, p. 50, pl. I, fig. 1), Sarcodictyon pacificum Hickson (1930a, p. 212, pl. 2, fig. 1) and 'Sympodium' Thomson and Dean (1931, p. 218, pl. 3, fig. 7) in the growth form and coloration of polyps. Crucial microscopic examination of the living specimens and sectioned preparations has $r \in$ vealed some remarkable characters generically distinct from these forms. It is devoid of spicules at all and covered with a thin perisarc-like envelope around the base of polyps and the stolon. Thus the form is to be referred to the genus Cornularia, which is the most primitive type of the stoloniferous Alcyonaria.

Of all the existing records of Cornularia, only two have been known as valid species, $C$. cornucopiae (Pallas) from the Mediterranean and $O$. minuta Light from the Philippines (Molander, 1929; Hickson, 1920b). Therefore, the following description of this new species may be of some interest in comparison with the known species.

\section{Genus Cornularia, LAMARCK, emend, MoLANDER}

Polyps united basally by ribbon-like stolons which contain more than one endodermal canal. Basal part of polyps and stolons protected by chitinous skeletal tubes. Spicule absent.

*Contributions from the Seto Marine Biological Laboratory, No. 143.

Publ. Seto Mar. Biol. Lab., I (3) 1950. 


\section{Cornularia komaii UTINOMI, n. sp.}

Colony: The colony has a ribbon-like stolon and widely separated polyps. It is found commonly under stones or on the underside of rocks in the littoral of Tanabe Bay, Prov. Kii. When fully expanded, the polyp body is uniformly pinkish and transparent. The basal part of the polyp and the stolon are covered with a thin chitinous envelope which is dirty brown in colour. These colours fade away and the whole colony becomes milky white after preservation in alcohol or formalin.

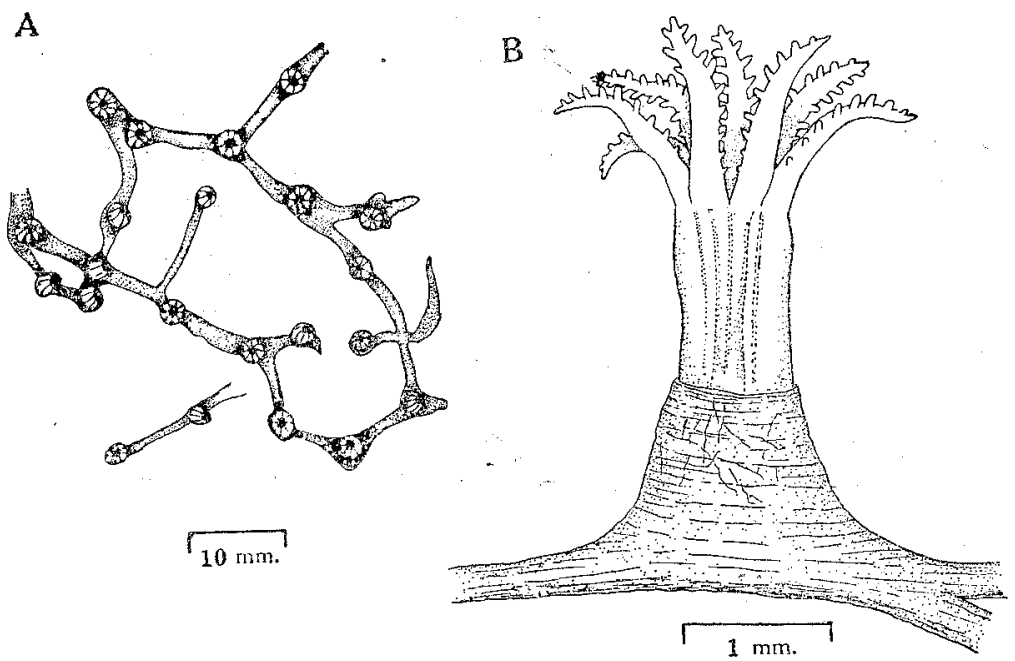

Fig 1. A, a colony of Cornularia komaï UTINoMt, n. sp. B, an expanded polyp

Stolon: The colony consists of an open network of narrow stolon strands having a wide mosh. These strands bear at wide intervals cone-shaped prominences. In many cases, the meshes are about 5-10 $\mathrm{mm}$ wide and the cones about 3-5 mm apart, so that the stolon may as usual arise branches at the bases of cones. The stolon is very narrow, flattened and brittle, measuring about 0.7-1.2 mm wide and about $0.2 \mathrm{~mm}$ thick. It, together with the cone-shaped basal part of polyps (anthostele), is covered invariably by a very thin, soft, chitinous envelope $(p)$, much like the perisarc of certain hydroids. Although voN KocH (1893), LIGHT (1915) and other later authors have called these envelopes 'horny' in texture, it is in fact chitinous as in hydroids. The envelope appears at a glance smooth, but when carefully examined under binocular microscope, wrinkled throughout and rather sticky, with adhering mud particles or diatoms. 
Serial sections clearly show that the stolon is occupied by 4-7 parallel rows of endodermal canals (en. c), arranged horizontally. The number of canals is variable according to the width of the stolon. These canals are comparatively wide and almost similar in diameter. They are surrounded by a thin, loose, less homo. geneous mesogloea $(\mathrm{mg})$ which is covered by a very thin epidermis (ec). The outer chitinous envelope is extremely thin and generally loosely attached to the ectoderm, leaving a considerable space between, although in some parts closely attached to it (Fig. 3). The arrangement of these canals is easily seen from the outside through the transparency of the body wall.
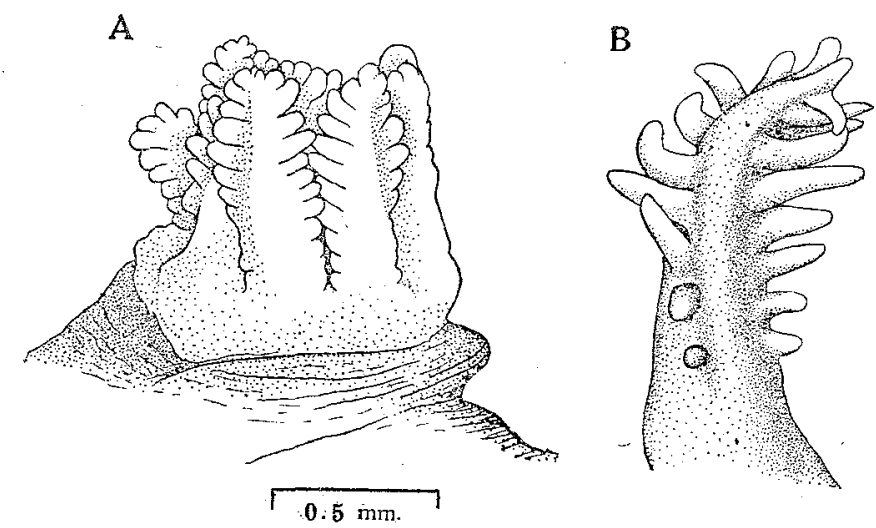

Fig. 2. A, partially expanded polyp. B, tentacle, oral side; highly magnified.

Polyp: The polyp body is indistinctly divisible into a retractile distal anthocodia and a proximal anthostele. In fully expanded state, the distinction between them is rather difficult owing to the non-spiculation of the body wall. When the anthocodia retracts, the anthostele becomes broader and forms a short rounded cone. The contracted colony looks, therefore, like a delicate string of minute, pinkish beads. The fully expanded polyp measures about $2.5-3 \mathrm{~mm}$ in length, not including the tentacles, and about $1 \mathrm{~mm}$ in diameter.

Anthostele: The anthostele is slightly contractile but non-retractile. When fully expanded, it is about $1.5 \mathrm{~mm}$ long, being subequal in length to the anthocodia. In a completely retracted polyp, it becomes a little shorter and wider, being about 1-1.5 $\mathrm{mm}$ long and 1-1.2 $\mathrm{mm}$ wide. The greater part of the anthostele is covered with a thin, dusky brown, chitinous envelope which extends from the stolon. Its distal portion is sometimes nude without any outer covering; this may be due to some extent to the condition of contraction.

Anthocodia: A full-expanded anthocodia is as long as the proximal anthostele or a little longer, and about $1 \mathrm{~mm}$ in diameter. Eight opaque, whitish lines run along 
the lines of attachment of the mesenteries from between the bases of tentacles down to the top of the anthostele. A slit-like mouth opens in the center of the crown of tentacles. It is about $0.2 \mathrm{~mm}$ in longer dimension and does not form any raised hypostome around it.

Tentacle: The tentacle is pinnate, rather short and non-pulsatile. The rachis is rather flattened, tongue-shaped, and about $1.3 \mathrm{~mm}$ long and $0.4 \mathrm{~mm}$ broad at the base. The pinnules are thick lobes, arranged in one row of 9-10 on either side of the tentacle. Their proximal two are of ten minute wartlike, the rest being long, fingerlike and about $0.08 \mathrm{~mm}$ broad at the base in the longest one (Fig. $2 \mathrm{~A}, \mathrm{~B}$ ).

A

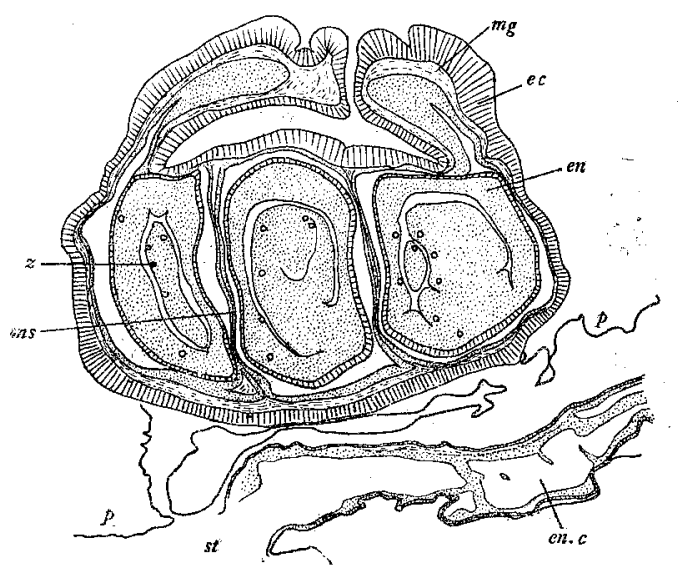

B

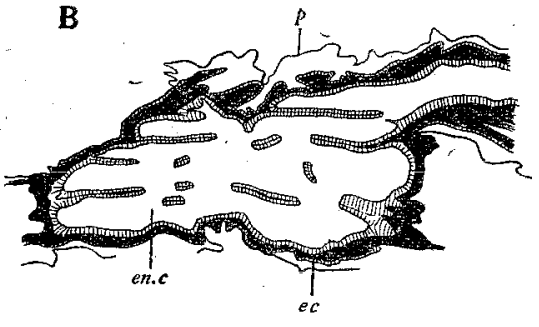

c

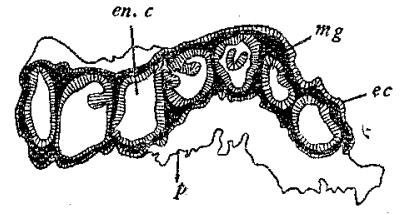

Fig. 3. Sections of polyp and stolon of Cornularia komaii, n. sp. A, longiuxdinal section of a polyp tightly contracted and a part of stolon, $\times 60 . \quad B$. horizontal section of a part of stolon, $\times 70$. C, cross section of stolon, $\times 70$. (ec ectoderm; en endoderm of contracted tentacle; $e n$. $c$ endodermal canal of stolon; $m g$ mesogloea; $m s$ mesentery; $p$ perisarc-like chitinous envelope; $z$ zooxanthella.]

Anatomy of the polyps: The structure of the anthocodia can only be satisfactorily studied when they are fully expanded. For minor details microscopic examination has been made on serial sections.

In sections the anthocodia and anthostele could not be exactly differentiated by the thickness of the body wall. In sections of contracted specimens, the wall of the tentacles is folded and much thickened, so that the average thickness of the ectoderm may be about $0.038 \mathrm{~mm}$ and that of the endoderm as well as the mesogloea about $0.023 \mathrm{~mm}$. The mesogloca of the polyp appears more homogencous and is occupied by the more densely packed hyalin substance than in that of the stolon. 
The pinuules of the tentacles bear a dense mass of nematocysts in the ectodermal layer, especially abundant at their extremities. The spicules are quite absent. When I wrote a preliminary report of this species (UTINOMI, 1950). I could not detect any trace of zooxantheliae (z) by mere superficial observation only. However, I have confirmed their occurrence in sections. They are naturally confined to the endoderm in the polyp, but none in the stolon. But they are very few in number an 1 deeply embedded in the tissue, so that it cannot be seen from the outside. A number of spermeries surrounded by capsules of mesogloeal and endodermal substances were found in sections. They were as usual attached to the mesenteries near the bottom of the coelenteron and numbered 9 in a single polyp. The largest one measured $0.01 \mathrm{~mm}$ in diameter.

\section{Remarks}

There is no doubt that this stoloniferan belongs to the genus Cornularia, the most primitive type of the Alcyonaria, as described above. The present specimen is easily distinguishable from others hitherto described by the character of the stolon and the structure of the anthocodia and tentacles. The most allied $C$. minuta (LIGHT, 1915) contains 2-4 endodermal cancls in the stolon, while the other $C$. cornucopiae (VoN KCcH, 1893) contains only one. In C. minuta, the stolon shows a nearly circular outline in cross section and apparently a somewhat irregular arrangement of canals. In the present form, however, the stolon is very thin, flattened, and contains a horizontally arranged layer of $4-7$ canals. It should therefore be reckoned as a new species to which I have pleasure in giving the name Cornularia komaii in honour of Prof. Taku Komal.

The present species shows some resemblances to a stoloniferan illustrated in IJIMA's "A Manual of Zoology" (1918, p. 330, fig. 381) as Cornularia sp. from Misaki. However, owing to the insufficient description of the latter, I am at present not in a position to express a definite opinion.

\section{LITERATURE}

Hicrson, S. J. 1930a. Some alcyonarians from the Eastern Pacific Ocean. Proc. Zool. Soc. London, 1930, no. 14, pp. 209-227.

1930b. On the classification of the Alcyonaria. Ibid., 1930, no. 15, pp. 229-252.

IJIMA, I. 1918. A manual of zoology. Tokyo. (in Japanese)

Koch, G. von 1890. Die Alcyonaceen des Golfes ron Neapel. Mt. Zool. Stat. Neapel, Bd. 9, Ht. 4, pp. 654-657. 
Light, S. F. 1915. Notes on Philippine Alcyonaria. Part V: Cornularia minuta, a new species. Philipp. Journ. Sci., vol. 10, no. 3, pp. 203-213.

Molander, A. R. 1929. Die Octactiniarien. Further Zool. Res. Swelish Antarctic Exped., vol. 2, no. 2, pp. 1-86.

Okubo, T. 1929. Clavularia gotoi, eine neue Art von Alcyonaria aus Sagami-Bai. Annot. Zool. Japon., vol. 12, no. 1, pp. 47-59.

Thomson, A. J. \& Dean, L. L. I. 1981. Alcyonacea of the Siboga Expedition. Siboga-Expediíie, mon. 13d, pp. 1-227.

Utinomi, H. 1950. Discovery of a new primitive alcyonarian, Cornularia. Kagaku, vol. 20 , no. 1 , pp. $37-38$. (in Japanese) 